\title{
INTERPRETASI HAKIM PENGADILAN AGAMA MALANG TERHADAP PASAL 55 UU NO. 21 TAHUN 2008 TENTANG PERBANKAN SYARIAH
}

\author{
Mohamad Nur Yasin dan M. Yusuf Subkhi \\ Fakultas Syariah UIN Maulana Malik Ibrahim Malang \\ Email: yasinm.nuryasin@yahoo.co.id
}

\begin{abstract}
Abstrak
This research reveals three causes of authority intersection in section 55 regulation Number 21, year 2008 on sharia banking. First, the transition of Religious Court after regulation Number 33 year 2006 on the changing of regulation Number 7 year 1989 on Religious Court is legalized. Second, there is an image that General Court is more popular than Religious Court. Third, there is socio-political influence and particular interests within the process of formulating the regulation. Judges in Religious Court of Malang are divided into two groups in interpreting section 55 regulation Number 21 year 2008 on Sharia Banking. Firstly, those who apply historical interpretation method argue that the section gives option towards dispute resolution forum. Secondly, those who apply grammatical method stated that section 55 is a historic, because the content has been included in section 49 Regulation Number 3 Year 2006 on the changing of Regulation Number 7 year 1989 on Religious Court which has implication towards the authority reduction of Religious Court on sharia banking.

Hasil penelitian menunjukkan kan tiga sebab persinggungan kewenangan dalam pasal 55 UU Nomor 21 Tahun 2008 Tentang Perbankan Syariah. Pertama, adanya masa transisi bagi Peradilan Agama setelah disahkannya UU Nomor 3 Tahun 2006 Tentang Perubahan Atas UU Nomor 7 Tahun 1989 Tentang Peradilan Agama. Kedua, adanya image bahwa Peradilan Umum lebih populer dari Peradilan Agama. Ketiga, adanya pengaruh sosial politik dan berbagai kepentingan dalam proses perumusan UU Nomor 21 Tahun 2008 Tentang Perbankan Syariah. Hakim Pengadilan Agama Malang terbagi dalam dua kelompok dalam menginterpretasikan pasal 55 UU Nomor 21 Tahun 2008 Tentang Perbankan Syariah. Pertama, kelompok yang menggunakan metode interpretasi sejarah berpendapat bahwa pasal 55 muncul untuk memberikan opsi terhadap forum penyelesai sengketa. Kedua, kelompok yang menggunakan metode gramatikal menyatakan, bahwa Pasal 55 UU Nomor 21 Tahun 2008 adalah ahistoris, karena keberadaannya telah ditampung dalam Pasal 49 UU Nomor 3 Tahun 2006 Tentang Perubahan Atas UU Nomor 7 Tahun 1989 Tentang Peradilan Agama yang berimplikasi pada tereduksinya kewenangan Pengadilan Agama di bidang perbankan syariah.
\end{abstract}

Kata Kunci: Persinggungan, Kewenangan, Peradilan Agama, Peradilan Umum

Indonesia adalah Negara Hukum. Hal ini termaktub dalam Pasal 1 ayat (3) UndangUndang Dasar Negara Republik Indonesia
(UUD NRI) $1945 .{ }^{1}$ Untuk menegakkan hukum ${ }^{1}$ Setelah perubahan UUD 1945 prinsip Negara hukum yang semual ditempatkan di dalam penjelasan UUD di pindahkan menjadi Pasal 1 ayat (3) dengan 
dan keadilan (to enforce the truth and justice), dibutuhkan kekuasaan (power). Hukum memerlukan kekuasaan untuk pelaksanaannya. ${ }^{2}$ Hukum tanpa kekuasaan adalah angan-angan, kekuasaan tanpa hukum adalah kezaliman. ${ }^{3}$ Kekuasaan diperlukan, karena hukum bersifat memaksa. ${ }^{4}$ Menurut Montesqieu, kekuasaan negara terbagi ke dalam tiga macam, antara satu dan lainnya harus terpisah, yaitu kekuasaan legislatif, kekuasaan eksekutif, dan kekuasaan yudikatif. Menurut Abdul Ghofur Anshori, inti tegaknya sebuah negara hukum sebenarnya lebih ditentukan oleh keberadaan lembaga yudikatif. Untuk menciptakan sebuah negara hukum, independensi kekuasaan kehakiman harus benar-benar dilaksanakan. ${ }^{5}$

Di Indonesia, kekuasaan kehakiman dilakukan oleh sebuah Mahkamah Agung dan badan peradilan yang berada di bawahnya dalam lingkungan Peradilan Umum, lingkungan Peradilan Agama, lingkungan Peradilan Militer, lingkungan Peradilan Tata Usaha Negara, dan oleh sebuah Mahkamah Konstitusi. ${ }^{6}$ Sedangkan, Pasal 24 ayat (1) dan (2) jo Pasal 18 UU Nomor 48 Tahun 2009 merupakan landasan sistem peradilan negera (state court system) di Indoesia, yang sejatinya dibagi dan terpisah berdasarkan yurisdiksi atau separation court system based on jurisdictions. ${ }^{7}$ Namun, dalam praktik sering terjadi persinggungan yurisdiksi antara satu pengadilan dengan pengadilan yang lain

kata Negara hukum saja.

${ }^{2} \mathrm{R}$. Arry Mth. Soekowathy, Orientasi Filsafat Hukum: Fungsi dan Relevansinya bagi Pembangunan (Yogyakarta: Philosofhy Press, 2001), h. 25.

${ }^{3}$ Mochtar Kusumaatmadja, Fungsi dan Perkembangan Hukum dalam Pembangunan Nasional, Lembaga Penelitian Hukum dan Kriminologi Fakultas Hukum Unpad, Bandung, tt. h. 4-5. Lihat juga dalam Sudikno Mertokusumo, Mengenal Hukum, Suatu Pengantar (Liberty: Yogyakarta, 1986), h. 19-20.

${ }^{4}$ Lili Rasjidi dan Ira Thania Rasjidi, Dasar-Dasar Filsafat dan Teori Hukum (Bandung: Citra aditya Bakti, 2004), h. 75.

${ }^{5}$ Abdul Ghofur Anshori, Peradilan Agama di Indonesia Pasca UU. No. 3 Tahun 2006 (Yogyakarta: UII Press, 2007), h. 33-34. Dan lihat juga Miriam Budiardjo, DasarDasar Ilmu Politik, Cet. Ke 21, (Jakarta: PT Gramedia Pustaka Utama, 2000), h. 155.

${ }^{6}$ Pasal 24 ayat (2)Undang-undang dasar 1945 jo Pasal 18 UU Nomor 48 Tahun 2009

${ }^{7}$ Yahya Harahap, Hukum Acara Perdata: Tentang Gugatan, Persidangan, Penyitaan, Pembuktian dan Putusan Pengadulan, (Jakarta: Sinar Grafika, 2005), h. 180-181. dalam satu sengketa yang sama, sehingga menimbulkan problema tersendiri. Contoh dari persinggungan yuridiksi tersebut adalah kewenangan Peradilan Agama dan Peradilan Umum dalam sengketa perbankan syariah.

Persinggungan antar dua peradilan di atas dalam menangani sengketa perbankan syariah bisa dilihat secarajelas dalam Pasal 55 UU Nomor 21 Tahun 2008 tentang perbankan Syariah yang menyebutkan: ${ }^{8}$ Pertama, Penyelesaian sengketa Perbankan Syariah dilakukan oleh pengadilan dalam lingkungan Pengadilan Agama. Kedua, Dalam hal para pihak telah memperjanjikan penyelesaian sengketa selain sebagaimana dimaksud pada ayat (1), penyelesaian sengketa dilakukan sesuai dengan isi Akad. Ketiga, Penyelesaian sengketa sebagaimana dimaksud pada ayat (2) tidak boleh bertentangan dengan Prinsip Syariah.

Dalam Penjelasan Pasal 55 ayat (2) UU Nomor 21 Tahun 2008 tentang perbankan Syariah disebutkan bahwa yang dimaksud dengan "Penyelesaian sengketa dilakukan sesuai dengan isi Akad" adalah upaya sebagai berikut: (a) Musyawarah; (b) Mediasi perbankan; (c) Melalui Badan Arbitrase Syariah Nasional (Basyarnas) atau lembaga arbitrase lain; dan/ atau (d) Melalui pengadilan dalam lingkungan Peradilan Umum.

Keberadaan Pasal 55 dan penjelasannya di atas memerlukan interpretasi yuridis, sehingga makna yang menjadi pesan utamanya tidak menimbulkan contradiction in terminis dan ketidakpastian hukum. Salah satu pihak yang bisa memberikan interpretasi yuridis adalah hakim sebagai pelaksana kekuasaan kehakiman. Hakim Pengadilan Agama (PA) Malang memiliki interpretasi yang unik dan tipologi yang beragam dalam menafsirkan Pasal 55 ayat (2) UU Nomor 21 Tahun 2008 tentang perbankan Syariah.

Kajian ini fokus pada dua permasalahan. Pertama, apa faktor yang melatarbelakangi kemunculan persinggungan kewenangan dalam Pasal 55 UU Nomor 21 Tahun 2008

\footnotetext{
${ }^{8}$ Undang-Undang Nomor 21 Tahun 2008 Tentang Perbankan Syariah Lembaran Negara Republik Indonesia Tahun 2008 Nomor 94.
} 
Tentang Perbankan Syariah menurut Hakim PA Malang. Kedua, bagaimana interpretasi Hakim PA Malang terhadap pasal 55 UU Nomor 21 Tahun 2008 Tentang Perbankan Syariah jika dilihat dari Pasal 49 UU Nomor 3 Tahun 2006 Tentang Perubahan Atas UU Nomor 7 Tahun 1989 Tentang Peradilan Agama.

\section{Kerangka Teoritik}

Menurut Satjipto Rahardjo, dalam Anthon Freddy Susanto, sejak hukum membuat tradisi untuk ditulis (written law), pembacaan terhadap teks hukum menjadi masalah yang penting sekali. Sejak pembacaan teks menjadi penting, maka penafsiran terhadap teks hukum tak dapat dihindarkan. Tidak berlebihan apabila dikatakan, bahwa penafsiran hukum merupakan jantung hukum. Hampir tidak mungkin hukum bisa dijalankan tanpa membuka pintu penafsiran. Penafsiran hukum merupakan aktivitas yang mutlak terbuka untuk dilakukan, sejak hukum berbentuk tertulis. Mengatakan bahwa teks hukum sudah jelas adalah satu cara saja bagi pembuat hukum untuk bertindak pragmatis dan secara diam-diam mengakui, bahwa dia mengalami kesulitan untuk memberi penjelasan. ${ }^{9}$

Interpretasi berasal dari kata dalam bahasa Latin interpretation yang memiliki beberapa makna. Pertama, penjelasan atau keterangan. Kedua, tafsiran mengenai suatu pernyataan, uraian atau naskah. Ketiga, mengemukakan arti luas atau lebih mendalam dari apa yang terlihat atau diketahui sepintas lalu. Keempat, mengungkapkan hal yang tersirat dari apa yang tersurat. Interpretasi merupakan kegiatan yang mengakibatkan bahwa kenyataan fisik atau psikologis dengan model konsepsional yang memberi arti dan tempat bagi kenyataan tersebut. ${ }^{10}$

Upaya untuk mencapai kehendak pembuat Undang-Undang (UU) dan dapat menjalankan UU sesuai dengan kenyataan sosial, hakim

\footnotetext{
${ }^{9}$ Anthon Freddy Susanto, Semiotika Hukum, Dari Dekonstruksi Teks Menuju Progresivitas Makna (Bandung: Refika Aditama, 2005), h. 1

${ }^{10}$ Anthon Freddy Susanto, Semiotika Hukum, Dari Dekonstruksi Teks Menuju Progresivitas Makna (Bandung: Refika Aditama, 2005), h. 1
}

menggunakan beberapa metode interpetasi. Pertama, metode subsumptif, hakim harus menerapkan suatu teks UU terhadap kasus in concreto, belum memasuki taraf penggunaan penalaran yang lebih rumit, tetapi sekadar menerapkan silogisme. Di dalamnya terjadi penyesuaian unsur UU terhadap peristiwa konkrit. ${ }^{11}$ Kedua, interpretasi gramatikal. Interpretasi gramatikal merupakan cara penafsiran atau penjelasan yang paling sederhana untuk mengetahui makna ketentuan UU dengan menguraikannya menurut bahasa, susunan kata, atau bunyinya. Interpretasi menurut bahasa ini selangkah lebih maju dari hanya sekadar membaca UU. ${ }^{12}$ Metode interpretasi gramatikal disebut juga metode objektif.

Ketiga, Interpretasi sejarah. Ini merupakan interpretasi berdasarkan pemeriksaan atau penelitian sejarah hukum atau sejarah perundang-undangan. Interpretasi sejarah hukum merupakan interpretasi luas yang meliputi interpretasi sejarah perundangundangan. Sedangkan interpretasi sejarah perundang-undangan bersifat lebih sempit, yaitu menyelidiki maksud pembuat peraturan dalam menetapkan peraturannya. ${ }^{13}$ Interpretasi sejarah kini cenderung untuk diartikan sebagai interpretasi sejarah perundang-undangan,yaitu sejarah terjadinya undang-undang atau ketentuan hukum tertulis itu. ${ }^{14}$ Dengan penafsiran menurut sejarah, hendak dicari maksud ketentuan UU, seperti yang dilihat oleh pembentuk UU pada waktu pembentukannya. Pikiran yang mendasari metode interpretasi ini adalah bahwa UU adalah kehendak pembentuk UU yang tercantum dalam teks UU. Di sini kehendak pembentuk UU yang menentukan. Interpretasi menurut sejarah UU ini disebut

\footnotetext{
${ }^{11}$ Achmad Ali, Menguak Tabir Hukum (Suatu Kajian Filosofis dan Sosiologis), (Jakarta: Toko Gunung Agung, 2002), h. 165

${ }^{12}$ Sudikno Mertokusumo, Mengenal Hukum, Suatu Pengantar, (Yogyakarta: Liberty, 2005), h. 170-171

${ }^{13} \mathrm{E}$ Utrecht dan Moh. Saleh Djindang, Pengantar dalam Hukum Indonesia, (Jakarta: Pustaka Sinar Harapan, 1989), h. 209

${ }^{14}$ Sujono Dirjosisworo, Pengantar Ilmu Hukum, Jakarta: Raja Grafindo Persada, 1999), h. 157. Mochtar Kusumaatmadja dan dan Arief Sidharta, Pengantar Ilmu Hukum, Suatu Pengenalan Pertama Ruang Lingkup Berlakunya Ilmu Hukum, (Bandung: Alumni. 1999), h. 101
} 
juga interpretasi subjektif, karena penafsir menempatkan diri pada pandangan subjektif pembentuk UU sebagai lawan interpretasi menurut bahasa yang disebut metode objektif. Sumber interpretasi adalah surat menyurat dan memory risalah DPRyang memberikan gambaran tentang kehendak pembentuk UU.

Suatu UU tidak terjadi begitu saja. UU selalu merupakan reaksi terhadap kebutuhan sosial untuk mengatur yang dapat dijelaskan secara historis. Setiap pengaturan dapat dilihat sebagai satu langkah dalam perkembangan masyarakat. Suatu langkah yang maknanya dapat dijelaskan apabila langkah-langkah sebelumnya diketahui juga. Ini meliputi seluruh lembaga yang terlibat dalam pelaksanaan UU.

Keempat, interpretasi gramatikal dan historis akan menghasilkan penafsiran yang lebih memuaskan apabila dikombinasikan dengan pemahaman, bahwa terjadinya sebuah UU selalu berkaitan dengan peraturan perundangundangan lain, dan tidak ada UU yang berdiri sendiri lepas sama sekali dari keseluruhan perundang-undangan. Menafsirkan UU sebagai bagian dari keseluruhan sistem perundangundangan dengan jalan menghubungkannya dengan UU lain seperti ini disebut penafsiran sistematis atau logis. ${ }^{15}$

\section{Metode Penelitian}

Jenis penelitian ini adalah penelitian lapangan (field research), yaitu penelitian yang data dan informasinya diperoleh dari kegiatan di lapangan penelitian. ${ }^{16}$ Penelitian ini lebih bersifat eksploratif, yaitu penelitian yang bertujuan menggali dan menemukan sesuatu yang baru bagi pengetahuan. ${ }^{17}$ Penelitian ini menggunakan pendekatan kualitatif, karena data yang dibutuhkan berupa sebaran-sebaran informasi yang tidak perlu dikuantifikasi. Dalam penelitian, data terbagi pada dua macam. Pertama, data primer, yaitu data yang didapat dari sumber pertama. ${ }^{18}$ Data primer ini digali

\footnotetext{
${ }^{15}$ Sudikno Mertokusumo, Mengenal Hukum, h. 172

${ }^{16}$ Supardi, Metodologi Penelitian Ekonomi dan Bisnis, (Yogyakarta: UII Press, 2005), h.34.

${ }^{17}$ Ibid., h. 23

${ }^{18}$ Soerjono Soejanto, Pengantar Penelitian Hukum (Jakarta: UI Press, 1986), h. 12. lihat juga Sutrisno
}

dengan menggunakan metode wawancara, ${ }^{19}$ bebas terpimpin, ${ }^{20}$ dan dengan pihak-pihak yang memiliki otoritas yuridis di lingkungan PA Malang secara langsung. ${ }^{21}$ Kedua, data Sekunder, yaitu data yang diperoleh dari sumber kedua. Data ini digali dengan menggunakan metode studi dokumen terhadap dokumen-dokumen, buku, jurnal-jurnal dan lainnya yang relevan. Metode studi dokumen digunakan dalam penelitian ini untuk mengumpulkan data berupa data-data tertulis yang mengandung keterangan dan penjelasan serta pemikiran tentang fenomena yang masih aktual. ${ }^{22}$

Setelah data terkumpul, tahapan selanjutnya adalah analisis data. Analisis data disesuaikan dengan tujuan penelitian. Secara teoritik, analisis data adalah proses penyederhanaan data kedalam bentuk yang lebih mudah dibaca dan dapat diinterprestasikan. ${ }^{23}$ Peneliti menggunakan analisis data kualitatif berupa informasi. Uraian dalam bentuk bahasa dikaitkan dengan data lain untuk mendapatkan kejelasan dan kebenaran. Sehingga, memperoleh gambaran baru atau menguatkan suatu gambaran yang sudah ada dan sebaliknya.

$\overline{\text { Hadi, Metodologi Research, jilid 3, (Yogyakarta: Yayasan }}$ Penerbitan Fakultas Psikologi UGM, 1986), h. 130.

${ }^{19}$ Wawancara (interview) mempunyai makna "percakapan dengan maksud tertentu, percakapan itu dilakukan oleh dua pihak yaitu pewawancara (interviewer) yang mengajukan pertanyaan dan yang diwancarai (interviewe) yang memberikan jawaban atas pertanyaan tersebut. Lihat Lexy J. Moeloeng, Metode Penelitian Kualitatif, (Bandung: PT. Remaja Rosda Karya, 2000), h. 135

${ }^{20}$ Suharsimi Arikunto membedakan interview menurut pelaksanaannya menjadi tiga macam yaitu: (1) Wawancara bebas (tanpa pedoman petanyaan). (2) Wawancara terpimpin (menggunakan draf pertanyaan. (3) Wawancara bebas terpimpin (kombinasi antara interview bebas dan interview terpimpin). Lihat Suharsimi Arikunto, Prosedur Penelitian Suatu Pendekatan Praktik, (Jakarta : Rineka Cipta, 1996), h. 145.

${ }^{21}$ Muhammad, Metodologi Penelitian Ekonomi Islam: Pendekatan Kuantitatif (Jakarta: Rajawali Press, 2008), h. 151.

${ }^{22}$ Muhammad, Metodologi Penelitian ...., h. 152.

${ }^{23}$ Masri Singaribun \& Sofian Efendi, Metode Penelitian Survey, (Jakarta : LP3ES, 1989), h. 192 
Persinggungan Kewenangan Pasal 55 UU Nomor 21 Tahun 2008 tentang Perbankan Syariah menurut Hakim Pengadilan Agama Kota Malang

Uraian tentang faktor-faktor yang melatarbelakangi persinggungan kewenangan penyelesaian sengketa perbankan syariah yang termaktub dalam Pasal 55 UU Nomor 21 Tahun 2008 tentang Perbankan Syariah dalam perspektif Hakim PA Malang dilakukan dengan mengurai pendapat para hakim. Berikut ini dipaparkan dua macam pendapat hakim tentang latar belakang persinggungan kewenangan tersebut.

Menurut Imron Rosyadi, ${ }^{24}$ dan Muh. Djamil, ${ }^{25}$ memiliki kesamaan sikap terhadap latar belakang persinggungan kewenangan penyelesaian sengketa perbankan syariah. Keduanya menegaskan bahwa Undang-Undang Nomor 21 Tahun 2008 Tentang Perbankan Syariah lahir dan disahkan Tahun 2008, jauh setelah bank syariah lahir pada Tahun 1991 dan beroperasi tahun 1992. Selisih jarak yang cukup lama ini memiliki potensi pemahaman yang berbeda dalam menyikapi keadaan ke depan. Artinya, pengaruh sosial politik dari berbagai kepentingan dapat mempengaruhi penyelesaian masalah kedepan. Khususnya masalah ekonomi syariah, dalam hal ini bank syariah meski setelah disahkannya Undang-Undang tersebut. Faktanya, setelah lahir Undang-Undang Nomor 21 Tahun 2008 Tentang Perbankan Syariah, penyelesaian sengketa perbankan syariah masih diajukan dan diselesaikan di Pengadilan Negeri. Fakta hukum yang demikian, dilaksanakan berdasarkan isi dari klausul perjanjian subjek hukum. Apapun yang terjadi, klausul perjanjian yang telah disepakati menjadi sebuah hukum yang bersifat mengikat, harus ditaati dan dilaksanakan oleh pembuat perjanjian.

Sesungguhnya UU Perbankan Syariah memiliki posisi kuat pada ranah hukum, sebagai payung hukum, dan pedoman pelaksanaan kegiatan operasional perbankan syariah pada umumnya. Pada pasal 55 ayat (2) UU Nomor

\footnotetext{
${ }^{24}$ Wawancara, 6/8/2012

${ }^{25}$ Wawancara, 9/8/2012
}

21 Tahun 2008 Tentang Perbankan Syariah, dalam penjelasannya disebutkan, "penyelesaian sengketa dilakukan sesuai dengan isi akad; dengan upaya musyawarah, mediasi perbankan, melalui Basyarnas (Arbitrase), dan pengadilan dalam lingkungan Peradilan Umum".

Persinggungan kewenangan yang dimaksud terdapat pada kalimat "Pengadilan dalam lingkungan Peradilan Umum". Artinya, sengketa yang terjadi antara orang Islam dan orang Islam atau non muslim yang tunduk pada UU Perbankan Syariah masuk dalam kewenangan Peradilan Agama. Dengan demikian, jelas bahwa penyelesaian sengketa perbankan syariah merupakan kewenangan Peradilan Agama. Selain itu, pada prinsipnya Peradilan Umum merupakan tempat penyelesaian sengketa secara litigasi bukan non-litigasi. Artinya, pradilan merupakan pelaksana kekuasaan kehakiman (judicial power) yang secara konstitusional disebut badan yudikatif (pasal 24 UUD NRI 1945).

Penulis menilai bahwa dalam perspektif Imron Rosyadi dan Muh. Djamil, persinggungan kewenangan terhadap sengketa perbankan syariah antara Peradilan Agama dan Peradilan Umum disebabkan oleh pengaruh sosial politik dan berbagai kepentingan yang mengitari proses perumusan UU Nomor 21 Tahun 2008 Tentang Perbankan Syariah.

Interpretasi terhadap Pasal 55 UU Nomor 21 Tahun 2008 Tentang Perbankan Syariah juga diberikan oleh Moh. Faisol dan Lukman Hadi. Keduanya menegaskan bahwa, hal yang paling dominan mengapa para pelaku perbankan syariah lari ke Pengadilan Negeri, karena dalam kontrak bakunya telah tertulis jika terjadi sengketa diselesaikan di Pengadilan Negeri. Selain itu sudah terpopulernya atau sudah familiarnya Pengadilan Negeri dimata masyarakat sejak sebelum adanya UndangUndang Perbankan Syariah lahir, sementara bank syariah telah berdiri dan beroperasi. Jadi sampai sekarang pengadilan agama khususnya kota malang belum menerima permohonan penyelesaian sengketa perbankan syariah. ${ }^{26}$

\footnotetext{
${ }^{26}$ Moh.Faisol, Wawancara, Malang 14/8/2012
} 
Pernyataan di atas dapat dipahami, bahwa telah terjadi kekosongan hukum setelah berdirinya bank syariah yang pertama kali, yaitu Bank Muamalat Indonesia pada tahun 1991. Bank syariah didirikan berdasarkan hukum yang ada dalam ketentuan UU Nomor 7 Tahun 1992 Tentang Perbankan. Dalam UU ini belum disebut secara eksplisit bank syariah, hanya disebutkan prinsip bagi hasil sebagaimana yang ditegaskan dalam pasal 6 huruf (m) dan pasal 13 huruf (c). ${ }^{27}$

Berdasarkan ketentuan tersebut, pemerintah mengeluarkan dua peraturan pemerintah tentang bank berdasarkan prinsip bagi hasil. Pertama, Peraturan Pemerintah Nomor 72 Tahun 1992 Tentang Bank Berdasarkan Bagi Hasil. Sehingga, UU Nomor 7 Tahun 1992 tentang Perbankan dan Peraturan Pemerintah di atas sebagai landasan hukum berdirinya Bank Umum Syariah. Kedua, Peraturan Pemerintah Nomor 73 Tahun 1992 Tentang Bank Perkreditan Rakyat Berdasarkan Bagi Hasil. Sehingga, UU Nomor 7 Tahun 1992 tentang Perbankan dan Peraturan Pemerintah ini menjadi landasan hukum berdirinya bank syariah pada periode ini.

Konsep tentang bank bagi hasil dalam UU dan dua Peraturan Pemerintah di atas belum mencakup secara tepat pengertian bank syariah yang memiliki cakupan lebih luas dari bank bagi hasil. Oleh karena itu, UU dan dua PP tersebut belum memberikan landasan hukum yang cukup kuat untuk pengembangan bank syariah di Indoensia, karena bank syariah hanya dipahami sebagai bank bagi hasil yang selanjutnya tunduk pada peraturan perbankan konvensional. Kondisi yang demikian memberi gambaran kepada masyarakat pada umumnya, bahwa bank syariah masih tetap tunduk pada perbankan konvensional. Hal ini ikut melatar belakangi perbedaan pemahaman makna dan

\footnotetext{
${ }^{27}$ Adapaun bunyi Pasal 6 huruf (m) selengkapnya adalah: Usaha Bank Umum Meliputi: menyediakan pembiayaan bagi nasabah berdasarkan prinsip bagi hasil sesuai dengan ketentuan yang ditetapkan dalam Peraturan Pemerintah. Sementara Pasal 16 huruf (c) berbunyi: Usaha Bank Perkreditan Rakyat meliputi: menyediakan pembiayaan bagi nasabah berdasarkan prinsip bagi hasil sesuai dengan ketentuan yang ditetapkan dalam Peraturan Pemerintah.
}

persinggungan UU Nomor 21 Tahun 2008 Tentang Perbankan Syariah. ${ }^{28}$

UU Perbankan Syariah disahkan pada 2008, jauh setelah pelaksanaan operasional perbankan syariah yang disebut dengan bank bagi hasil. Dalam waktu sekian tahun sampai sekarang masih terdapat ketidakpahaman masyarakat Muslim, khususnya pelaku operasional perbankan syariah baik nasabah atau institusi bank syariah, dalam penerapan UU Nomor 21 Tahun 2008 Tentang Perbankan Syariah. Hal ini, terbukti dari pelaksanaan penyelesaian sengketa perbankan syariah yang selalu dibawa ke Peradilan Umum berdasarkan pada perjanjian yang telah disepakati. Sementara, sengketa yang berhubungan dengan perbankan syariah atau ekonomi syariah sesungguhnya telah masuk dalam kewenangan absolut Peradilan Agama sesuai dengan UU Nomor 3 Tahun 2006 Tentang Perubahan Atas UU Nomor 7 Tahun 1989 Tentang Peradilan Agama. Interpretasi Moh. Faisol dapat dipahami, bahwa yang menjadi penyebab terjadinya persinggungan kewenangan menangani sengketa adalah karena ketidak pahaman masyarakat Muslim, khususnya pelaku operasional perbankan syariah baik nasabah atau bank syariah sendiri, dalam penerapan UU Nomor 21 Tahun 2008 Tentang Perbankan Syariah.

Munasik,, 29 menuturkan bahwa "Kewenangan absolut Pengadilan Agama akan luntur atau disebut hilang jika dalam klausul isi perjanjian kedua pihak yang telah disepakati menyebutkan, "Jika terjadi sengketa, maka di selesaikan di Pengadilan Negeri" pernyataan yang demikian ini bersifat mengikat dan harus ditaati oleh penulis/ pengguna sebab perjanjian adalah hukum. Sehingga sengketa yang demikian, jika masuk dalam pengadilan agama akan ditolak, meskipun dengan alasan tidak disengaja ataupun karena ketidaktahuan. Keadaan yang demikian ini menunjukkan terjadinya masa transisi bagi Peradilan Agama dalam menyelesaikan sengketa perbankan syariah.

${ }^{28}$ Lukman Hadi, Wawancara, Malang 4 Agustus 2012

${ }^{29}$ Wawancara tanggal 22/8/2012 
Terjadinya masa transisi yang demikian merupakan salah satu dampak dari kekosongan hukum yang pernah terjadi di lingkungan Peradilan Agama, khususnya setelah mengalami beberapa kali reduksi kewenangan di lingkungan Peradilan Agama. Posisi Peradilan Agama belum kokoh akibat kepentingan politik disusul lahirnya bank syariah yang belum memiliki payung hukum secara jelas dan masih menginduk kepada UU Nomor 7 Tahun 1992 Tentang Perbankan. Sehingga, disebut bank bagi hasil. Namun, pada 1998 sampai 2008 UU Nomor 7 Tahun 1992 Tentang Perbankan disempurnakan dengan UU Nomor 10 Tahun 1998 Tentang Perbankan. Dalam UU Nomor 10 Tahun 1998 Tentang Perbankan disebutkan beberapa kententuan perbankan syariah. Lahirnya UU Nomor 10 Tahun 1998 Tentang Perbankan menjadikan landasan hukum perbankan syariah semakin kuat. UU Nomor 10 Tahun 1998 memberikan landasan kelembagaan dan operasional untuk perkembangan bank syariah secara komprehensif.

Seiring disahkannya UU Nomor 3 Tahun 2006 Tentang Perubahan Atas UU Nomor 7 Tahun 1989 Tentang Peradilan Agama, kewenangan Pengadilan Agama sebagaimana dirumuskan dalam Pasal 49 UU Nomor 7 Tahun 1989 Tentang Peradilan Agama menjadi lebih luas, sebagaimana disebutkan dalam Pasal 49 UU Nomor 3 Tahun 2006 Tentang Perubahan Atas UU Nomor 7 Tahun 1989 Tentang Peradilan Agama, yang berbunyi: "Pengadilan agama bertugas dan berwenang memeriksa, memutus, dan menyelesaikan perkara di tingkat pertama antara orang-orang yang beragama Islam di bidang: perkawinan; waris; wasiat; hibah; wakaf; zakat; infaq; shadaqah; dan ekonomi syariah".

Sejak 2008 perbankan syariah memiliki UU tersendiri, yaitu UU Nomor 21 Tahun 2008 Tentang Perbankan Syariah. UU ini merupakan pedoman operasional yang mengatur perbankan syariah secara spesifik. Dengan demikian jelas adanya, bahwa latar belakang persinggungan kewenangan pasal 55 UU Nomor 21 Tahun 2008 Tentang Perbankan Syari'ah menurut hakim Pengadilan Agama Malang adalah adanya masa transisi yang dialami Peradilan
Agama akibat kekosongan hukum, khususnya dalam pengaturan Perbankan Syariah. Hal ini terjadi, karena kelahiran perbankan syariah dan operasionalnya ada lebih dulu dari pada UU Nomor 21 Tahun 2008 Tentang Perbankan Syariah.

Lebih lanjut, secara umum masyarakat muslim masih banyak yang beracara di Peradilan Umum sebagai tempat penyelesaian perkara yang terjadi di bank syariah, karena posisi Peradilan Umum dianggap lebih populer dari pada Peradilan Agama dalam menyelesaikan sengketa perbankan. Begitu juga adanya pemahaman masyarakat Muslim yang menganggap, bahwa aturan bank syariah menginduk pada aturan bank konvensional. Keadaan yang demikian dibuktikan dengan adanya klausul dalam perjanjian baku antara nasabah dan perbankan yang disepakati oleh para pihak dengan menuliskan bahwa "Bila terjadi penyelesaian sengketa, diselesaiakan di Pengadilan Negeri. ${ }^{\prime \prime 30}$ Menurut Munasik, faktor yang menjadi penyebab terjadinya persinggungan kewenangan antara Peradilan Agama dan Peradilan Umum dalam penyelesaian sengketa perbankan syariah adalah adanya masa transisi Peradilan Agama dalam menyelesaikan sengketa ekonomi syariah.

\section{Interpretasi Hakim PA Malang terhadap Pasal 55 UU Nomor 21 Tahun 2008 Tentang Perbankan Syariah Perspektif Pasal 49 UU Nomor 3 Tahun 2006}

Analisis pada bagian ini dilakukan dengan menempatkan secara sejajar antara Pasal 55 UU Nomor 21 Tahun 2008 Tentang Perbankan Syariah dan Pasal 49 UU Nomor 3 Tahun 2006 Tentang Perubahan Atas UU Nomor 7 Tahun 1989 Tentang Peradilan Agama. Pasal 55 UU Nomor 21 Tahun 2008 tentang Perbankan Syariah menyebutkan: (1) Penyelesaian sengketa Perbankan Syariah dilakukan oleh Pengadilan dalam lingkungan Peradilan Agama; (2) Dalam hal para pihak telah memperjanjikan penyelesaian sengketa selain sebagaimana dimaksud pada ayat (1), penyelesaian sengketa dilakukan sesuai

\footnotetext{
${ }^{30}$ Wawancara tanggal 22/8/2012
} 
dengan isi akad; (3) Penyelesaian sengketa sebagaimana dimaksud pada ayat (2) tidak boleh bertentangan dengan Prinsip Syraiah.

Selanjutnya dalam penjelasan pasal 55 ayat (2) UU Nomor 21 Tahun 2008 Tentang Perbankan Syariah menyebutkan bahwa yang dimaksud dengan "Penyelesaian sengketa dilakukan sesuai dengan isi Akad" adalah upaya sebagai berikut: (a) Musyawarah; (b) Mediasi Perbankan; (c) Melalui Badan Arbitrase Syariah Nasional (Basyarnas) atau lembaga arbitrase lain; dan/ atau (d) Melalui pengadilan dalam lingkungan Peradilan Umum. Kemudian dalam Pasal 49 UU Nomor 3 Tahun 2006 Tentang Perubahan Atas UU Nomor 7 Tahun 1989 Tentang Peradilan Agama disebutkan bahwa Pengadilan agama bertugas dan berwenang memeriksa, memutus, dan menyelesaikan perkara di tingkat pertama antara orang-orang yang beragama Islam di bidang: (a) perkawinan; (b) waris; (c) wasiat; (g). hibah; (e) wakaf; (f) zakat; (g). infaq; (h) shadaqah; dan (i) ekonomi syariah.

Lebih lanjut, dalam penjelasan Pasal 49 huruf (i) UU Nomor 3 Tahun 2006 Tentang Perubahan Atas UU Nomor 7 Tahun 1989 Tentang Peradilan Agama disebutkan bahwa yang dimaksud dengan ekonomi syariah adalah perbuatan atau kegiatan usaha yang dilaksanakan menurut prinsip syariah, antara lain meliputi: (a) bank syariah; (b) lembaga keuangan mikro syariah; (c) asuransi syariah; (d) reasuransi syariah; (e) reksadana syariah; (f) obligasi syariah dan surat berharga berjangka menengah syariah; (g) sekuritas syariah; (h) pembiayaan syariah; (i) pegadaian syariah; (j) dana pensiun lembaga keuangan syariah; dan (k) bisnis syariah.

Analisis pada bagian ini fokus pada pendapat Hakim Pengadilan Agama Malang terhadap pasal 55 UU Nomor 21 Tahun 2008 Tentang Perbankan Syariah dilihat dari pasal 49 UU Nomor 3 Tahun 2006 Tentang Perubahan Atas UU Nomor 7 Tahun 1989 Tentang Peradilan Agama. Mayoritas Hakim Pengadilan Agama Malang memiliki kesamaan dalam memberikan pendapat terhadap pasal-pasal di atas.
Pertama, poin-poin pemikiran Imron Rosyadi, Lukman Hadi, dan Moh. Faisol bisa disarikan yaitu: ${ }^{31}$ "Sesungguhnya masalah ekonomi syariah (dalam hal ini Perbankan Syariah) merupakan kewenangan absolut Pengadilan Agama bila dipandang dari Undang-Undang Nomor 3 Tahun 2006 Tentang Perubahan Atas UU Nomor 7 Tahun 1989 Tentang Peradilan Agama. Termasuk Penyelesaian Sengketa Perbankan Syariah, seharusnya diselesaikan dan diajukan ke Pengadilan Agama. Namun, karena dalam perjalanan kegiatannya pelaku perbankan syariah memiliki perjanjian yang telah disepakati oleh pelaku bank syariah, maka sifat dari perjanjian tersebut adalah memaksa. Umumnya, dalam klausul perjanjian disebutkan, bahwa apabila terjadi sengketa, maka diselesaikan di Pengadilan Negeri. Dengan demikian, secara otomatis kewenangan Pengadilan Agama luntur atau hilang. Meskipun sengketa tersebut diajukan ke Pengadilan Agama, maka Pengadilan Agama tidak berhakuntuk menyelesaikannya dan bahkan dianjurkan untuk menolak sengketa tersebut. Kemungkinan besar hal ini disebabkan karena kelemahan orang Islam sendiri. Maksudnya, karena ketidakpahaman atau ketidaktahuan terhadap Undang-Undang Perbankan Syariah atau bahkan karena disengaja. Bisa jadi, hal ini karena efek ringan dari sosial politik yang saling memiliki kepentingan pribadi."

Pemikiran Hakim PA Malang di atas bisa dipahami, bahwa para Hakim PA Malang secara kolektif berpendapat bahwa, pada dasarnya masalah Perbankan Syariah masuk dalam kewenangan absolut Peradilan Agama sesuai dengan UU Nomor 3 Tahun 2006 Tentang Perubahan Atas UU Nomor 7 Tahun 1989 Tentang Peradilan Agama. Termasuk juga masalah penyelesaian sengketa perbankan syariah yang diatur dalam pasal 55 Undang-Undang Nomor 21 Tahun 2008 Tentang Perbankan Syariah. Pada hakikatnya, sengketa perbankan syariah diselesaikan oleh Peradilan Agama. Namun, apabila para pihak memperjanjikan penyelesaian sengketa di luar Peradilan

\footnotetext{
${ }^{31}$ Imron Rosyadi, Wawancara, Malang. 8/8/2012, Lukman Hadi, Wawancara, Malang 21/8/2012, Moh. Faisol,. Wawancara, Malang. 16/8/2012
} 
Agama, maka boleh berdasarkan isi akad yang diperjanjikan dan tidak boleh bertentangan dengan prinsip syariah.

Kondisi yang demikian memberikan pilihan hukum terhadap subjek hukum untuk menyelesaikan sengketanya. Dengan adanya pilihan hukum tersebut, dapat memberi kebebasan kepada para pihak untuk memilih tempat menyelesaikan sengketa. Tetapi muncul dugaan kemungkinan adanya pengaruh sosial politik yang dapat mempengaruhi hal tersebut dengan dimasukkannya opsi Peradilan Umum sebagai salah satu pilihan penyelesaian sengketa sebagaimana termuat dalam penjelasan Pasal 55 UU No. 21 Tahun 2008 huruf (d).

Perjanjian di atas merupakan kelemahan dari subjek hukum atau internal umat Islam yang belum dapat memahami peraturan perundangundangan yang mengatur kegiatan perbankan syariah, baik karena memang betul-betul tidak tahu atau karena sengaja. Sementara itu, UU No 3 Tahun 2006 Tentang Tentang Perubahan Atas UU Nomor 7 Tahun 1989 Tentang Peradilan Agama dengan jelas menyebutkan, bahwa masalah ekonomi syariah (dalam hal ini perbankan syariah) menjadi kewenangan Peradilan Agama. Namun, mengapa dalam pasal 55 UU Nomor 21 Tahun 2008 Tentang Perbankan Syariah penyelesaian sengketa boleh diselesaikan di luar Peradilan Agama, dalam hal ini Peradilan Umum. Selain Peradilan Umum merupakan tempat menyelesaikan sengketa secara litigasi, sengketa perbankan syariah merupakan masalah personalitas antara orang Islam dengan orang Islam atau non Muslim yang tunduk pada hukum Islam dan harus diselesaikan di Peradilan Agama. Hal ini masih berkaitan dengan masa transisi Peradilan Agama atas kewenangan absolut ekonomi syariah dan akibat kekosongan hukum antara disahkannya UU Perbankan Syariah dan operasional perbankan syariah. Jadi, tidak seutuhnya bahwa kondisi demikian adalah kesalahan para subjek hukum atau kesalahan pihak yang berwenang. Akibat dari tarik ulur kepentingan politik juga mempengaruhi keadaan yang demikian.
Dengan demikian, Hakim PA Malang berharap dilakukannya revisi UU Perbankan Syariah khusunya pasal 55 mengenai penyelesaian sengketa perbankan syariah yang berkaitan dengan UU lain yang masih berkaitan, seperti UU Nomor 3 Tahun 2006 Tentang Perubahan Atas UU Nomor 7 Tahun 1989 Tentang Peradilan Agama. Sebab, masalah perbankan syariah masuk dalam ekonomi syariah yang merupakan kewenangan absolut Peradilan Agama. Selain itu, sifat UU seharusnya mudah dipahami, jelas, dan tidak menimbulkan bersinggungan antara UU yang satu dan UU yang lain, sebagaimana yang masih saling berkaitan.

Paparan di atas dapat dijelaskan, bahwa metode yang dipakai oleh hakim di atas adalah metode interpretasi menurut sejarah, yaitu hendak dicari maksud ketentuan Pasal 55 UU Nomor 21 Tahun 2008 Tentang Perbankan Syariah oleh pembentuk UU pada waktu pembentukannya, yaitu memberikan banyak pilihan kepada para pihak untuk memilih forum penyelesaian sengketa perbankan syariah dengan catatan harus sesuai dengan prinsip syariah.

Kedua, intisari pemikiran Muh. Djamil dan Munasik, ${ }^{32}$ menyatakan bahwa: "Secara yuridis, pencantuman Pasal 55 UU Nomor 21 Tahun 2008 adalah ahistoris, mengingat keberadaannya telah ditampung dalam Pasal 49 UU Nomor 3 Tahun 2006 Tentang Perubahan Atas UU Nomor 7 Tahun 1989 Tentang Peradilan Agama yang secara tegas memberikan kewenangan secara penuh kepada institusi Pengadilan Agama untuk menerima dan menyelesaikan sengketa ekonomi syariah yang di dalamnya juga termasuk perbankan syariah. UU Nomor 3 Tahun 2006 dirubah menjadi UU Nomor 50 Tahun 2009 dan ketentuan Pasal 49 tetap dipertahankan."

Mengacu pada paparan di atas, secara horisontal Pasal 55 UU Nomor 21 Tahun 2008 Tentang Perbankan Syariah tidak sinkron dan tidak harmonis, bahkan bertentangan dengan peraturan yang telah ada, yaitu Pasal 49 UU

\footnotetext{
${ }^{32}$ Muh. Djamil, Wawancara, Malang. 10/8/2012, Munasik, Wawancara, Malang. 24/8/2012
} 
Nomor 3 Tahun 2006 jo UU Nomor 50 Tahun 2009. Penambahan pasal yang mengatur penyelesaian sengketa tersebut tidak tepat dengan semangat reformasi hukum yang disusung oleh sistem peradilan satu atap di Indonesia dan secara vertikal bertentangan dengan UUD NRI 1945.

Masih menurut kedua hakim di atas, bahwa terlepas dari kesalahan secara yuridis, Pasal 55 UU Nomor 21 Tahun 2008 Tentang Perbankan Syariah yang menjadi dasar hukum bagi kewenangan Peradilan Umum dalam menerima, memutus, dan menyelesaikan sengketa perbankan tetap memiliki implikasi. Ada beberapa implikasi yang bisa terjadi. Pertama, mengakibatkan tidak utuhnya kompetensi absolut Peradilan Agama di bidang perbankan syariah sebagaimana dijelaskan dalam Pasal 49 UU Nomor 3 Tahun 2006 Tentang Perubahan Atas UU Nomor 7 Tahun 1989 Tentang Peradilan Agama dan mengakibatkan pembatasan sekaligus menimbulkan reduksi kewenangan Peradilan Agama di bidang perbankan syariah. Sebab, apabila para pihak menentukan dalam akad, bahwa sengketa perbankan syariah yang terjadi akan diselesaikan di Peradilan Umum, maka sengketa tersebutjelas tidak lagi termasuk kewenangan absolut Peradilan Agama, melainkan kewenangan absolut Peradilan Umum.

Hakim PA Malang dalam melakukan interpretasi menggunakan metode interpretasi gramatikal dan historis, bahwa terjadinya sebuah undang-undang selalu berkaitan dengan peraturan perundang-undangan lain dan tidak ada undang-undang yang berdiri sendiri lepas sama sekali dari keseluruhan perundangundangan. Keterkaitan dimaksud adalah antara Pasal 55 UU Nomor 21 Tahun 2008 dan Pasal 49 UU Nomor 3 Tahun 2006 yang sama-sama

\section{DAFTAR PUSTAKA}

Undang-Undang Dasar tahun 1945

Undang-Undang Nomor 21 Tahun 2008 tentang Perbankan Syariah

Undang-undang Nomor 3 Tahun 2006 Penga- fokus pada kewenangan Peradilan Agama di bidang perbankan syariah.

\section{Kesimpulan}

Berdasarkan uraian di atas ada beberapa kesimpulan yang bisa dikemukakan. Pertama, menurut Hakim PA Malang, ada beberapa faktor yang melatarbelakangi persinggungan kewenangan dalam pasal 55 UU Nomor 21 Tahun 2008 Tentang Perbankan Syariah. (1) Adanya masa transisi bagi Peradilan Agama setelah disahkannya UU Nomor 3 Tahun 2006 Tentang Perubahan Atas UU Nomor 7 Tahun 1989 Tentang Peradilan Agama yang memiliki kewenangan baru dalam penyelesaian sengketa perbankan syariah. (2) Lebih populernya Peradilan Umum dari pada Peradilan Agama dalam menyelesaikan sengketa Bank. (3) Pengaruh kepentingan sosial politik dari berbagai pihak yang mengitari perumusan UU Nomor 21 Tahun 2008.

Kedua, hakim PA Malang dalam melakukan interpretasi terhadap pasal 55 UU Nomor 21 Tahun 2008 Tentang Perbankan Syariah terbagi dalam dua kelompok. Pertama, ada hakim yang menggunakan metode sejarah dengan menyatakan, bahwa Pasal 55 pada dasarnya memberikan banyak pilihan kepada para pihak untuk memilih forum penyelesaian sengketa perbankan syariah dengan catatan harus sesuai dengan prinsip syariah. Kedua, ada hakim yang menggunakan metode interpretasi gramatikal dan historis yang menyatakan, bahwa secara yuridis, Pasal 55 UU Nomor 21 Tahun 2008 adalah ahistoris mengingat keberadaannya telah ditampung dalam Pasal 49 UU Nomor 3 Tahun 2006 Tentang Perubahan Atas UU Nomor 7 Tahun 1989 Tentang Peradilan Agama yang berimplikasi pada tereduksinya kewenangan Peradilan Agama di bidang perbankan syariah.

dilan Agama

Ali, Achmad. Menguak Tabir Hukum (Suatu Kajian Filosofis dan Sosiologis), Jakarta: Toko Gunung Agung, 2002 
Anshori, Abdul Ghofur. Peradilan Agama di Indonesia Pasca UU. No. 3 Tahun 2006, Yogyakarta: UII Press, 2007.

Arikunto, Suharsimi. Prosedur Penelitian Suatu Pendekatan Praktik, Jakarta : Rineka Cipta, 1996.

Budiardjo, Miriam. Dasar-Dasar Ilmu Politik, Jakarta: PT Gramedia Pustaka Utama, 2000.

Dirjosisworo, Sujono. Pengantar Ilmu Hukum, Jakarta: Raja Grafindo Persada, 1999.

Hadi, Sutrisno. Metodologi Research, jilid 3, Yogyakarta: Yayasan Penerbitan Fakultas Psikologi UGM, 1986.

Harahap, Yahya. Hukum Acara Perdata: Tentang Gugatan, Persidangan, Penyitaan, Pembuktian dan Putusan Pengadulan, Jakarta: Sinar Grafika, 2005.

Kusumaatmadja, Mochtar. Fungsi dan Perkembangan Hukum dalam Pembangunan Nasional, Lembaga Penelitian Hukum dan Kriminologi Fakultas Hukum Unpad, Bandung, tt.

Kusumaatmadja, Mochtar, dan dan AriefSidharta. Pengantar Ilmu Hukum, Suatu Pengenalan Pertama Ruang Lingkup Berlakunya Ilmu Hukum, Bandung: Alumni. 1999.

Mertokusumo, Sudikno. Mengenal Hukum, Suatu
Pengantar, Liberty: Yogyakarta, 1986.

Muhammad. Metodologi Penelitian Ekonomi Islam: Pendekatan Kuantitatif, Jakarta: Rajawali Press, 2008.

Moeloeng, Lexy J. Metode Penelitian Kualitatif, Bandung: PT. Remaja Rosda Karya, 2000.

Rasjidi Lili, dan Ira Thania Rasjidi. Dasar-Dasar Filsafat dan Teori Hukum, Bandung: Citra aditya Bakti, 2004.

Singaribun, Masri \&Sofian Efendi. Metode Penelitian Survey, Jakarta : LP3ES, 1989.

Soekowathy, R. Arry Mth. Orientasi Filsafat Hukum: Fungsi dan Relevansinya bagi Pembangunan, Yogyakarta: Philosofhy Press, 2001

Supardi. Metodologi Penelitian Ekonomi dan Bisnis, Yogyakarta : UII Press, 2005.

Susanto, Anthon Freddy. Semiotika Hukum, Dari Dekonstruksi Teks Menuju Progresivitas Makna, Bandung: Refika Aditama, 2005.

Soekanto, Soerjono. Pengantar Penelitian Hukum, Jakarta: UI Press, 1986.

Utrecht, E dan Moh. Saleh Djindang. Pengantar dalam Hukum Indonesia, Jakarta: Pustaka Sinar Harapan, 1989. 